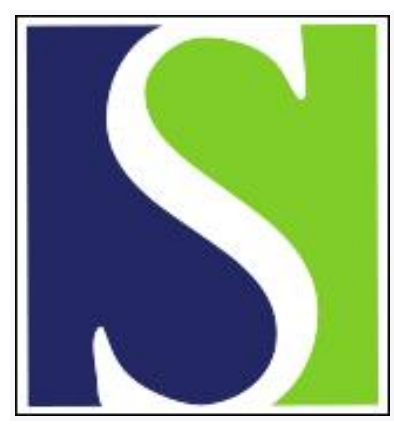

Scand J Work Environ Health 1993;19(4):264-270

https://doi.org/10.5271/sjweh.1475

Issue date: 01 Aug 1993

Neurobehavioral functions among workers exposed to manganese ore.

by Chia SE, Foo SC, Gan SL, Jeyaratnam J, Tian CS

Affiliation: Department of Community, Occupational \& Family Medicine, National University of Singapore.

This article in PubMed: www.ncbi.nlm.nih.gov/pubmed/8235515

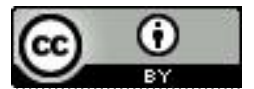




\title{
Neurobehavioral functions among workers exposed to manganese ore
}

\author{
by SE Chia, MSc(OM), ${ }^{1}$ SC Foo, PhD,${ }^{1}$ SL Gan, MSc(OM) ${ }^{2} \mathrm{~J}$ Jeyaratnam, PhD, ${ }^{1}$ \\ CS Tian, MMed (Psychiatry)
}

\begin{abstract}
CHIA SE, FOO SC, GAN SL, JEYARATNAM J, TIAN CS. Neurobehavioral functions among workers exposed to manganese ore. Scand J Work Environ Health 1993;19:264 - 70. The Neurobehavioral Core Test Battery of the World Health Organization was performed on 17 baggers (mean age 36.6 years) in a manganese ore milling plant and 17 referents (mean age 35.7 years). The baggers had a mean exposure period of 7.4 (range 1-14) years with a mean blood manganese concentration of 25.3 (range $15-92.5) \mu \mathrm{g} \cdot \mathrm{l}^{-1}\left[0.46(0.27-1.68) \mu \mathrm{mol} \cdot \mathrm{l}^{-1}\right]$. Of the 37 symptoms related to the nervous system, 20 were more frequently reported by the exposed workers. No significant differences were noted between the nerve conduction of the median and ulnar nerves of the dominant forearm of the two groups. The exposed workers had significantly poorer motor speed, visual scanning, visuomotor coordination, visuomotor and response speed, and visuomotor coordination and steadiness. A clinical examination did not reveal any abnormality among the two groups. Hence a neurobehavioral test battery may be a more sensitive method than a clinical examination in detecting early changes in motor function among manganese-exposed workers.
\end{abstract}

Key terms: blood, motor function, nerve conduction, urine.

Toxic effects of chronic exposure to manganese in the workplace were first reported in the early 19th century by Couper in Chile (1) and subsequently by other researchers $(2-5)$.

Manganese exerts its effect mainly on the central nervous system (6). With high exposure, a worker can experience psychiatric symptoms of hallucinations, emotional lability, and compulsive and aberrant behavior in the acute phase. Later, symptoms of muscular weakness, impaired speech, headache, clumsiness, tremor, mild rigidity, and masklike facial expressions appear. The later symptoms of chronic manganese poisoning are similar to those of Parkinson's disease.

Neuropsychiatric disturbances such as asthenia, profuse sweating, sialorrhea, insomnia, weeping, impotence, irritability, lack of sociability, uncontrolled laughter, mild euphoria, and suspiciousness have also been observed ( $7-9$ ).

However, studies of the effects of chronic exposure to manganese on neurobehavioral functions are few. Wennberg et al (10) studied a group of 30 men recruited from steel smelting works with manganese exposure. They reported an increased frequency of

1 Department of Community, Occupational \& Family Medicine, National University of Singapore, Singapore.

2 Department of Industrial Health, Ministry of Labour, Singapore.

3 Department of Psychological Medicine, National University Hospital, Singapore.

Reprint requests to: Dr S-E Chia, Department of Community, Occupational \& Family Medicine, National University of Singapore, National University Hospital, Lower Kent Ridge Road, Singapore 0511, Republic of Singapore. symptoms of behavioral disorders, slower reaction time scores, and impaired finger-tapping and digitspan performance in the exposed group. The workers were taken from steel smelting plants where other metals such as mercury and lead could have possibly confounded the findings (11). Hua \& Huang (12) examined neurobehavioral functions in two groups of workers with chronic exposure to industrial manganese and in two reference groups. They reported no evidence of neurobehavioral impairment among workers, without parkinsonian symptoms, who were chronically exposed to manganese. The present study was thus conducted to investigate possible effects of manganese exposure and neurobehavioral impairment.

\section{Subjects and methods}

\section{Study population}

The study was carried out at two manganese ore milling factories (A and B) in Singapore. These factories were the only manganese ore milling factories in Singapore. The process is fairly simple. Manganese ore is fed into the ball mill and the milled manganese ore is subsequently bagged by the workers. The latter operation is very dusty. All of the workers (both feeding and bagging sections) from both mills with work experience of more than one year and without central or peripheral nervous system illness or psychiatric disorders were included in the study. Seventeen male workers fulfilled these criteria.

A reference group of 17 male subjects matched for age and years of education were selected from the 
Table 1. Characteristics of the study population.

\begin{tabular}{|c|c|c|c|c|c|c|c|c|}
\hline \multirow{2}{*}{ Group } & \multicolumn{2}{|c|}{$\begin{array}{c}\text { Age } \\
\text { (years) }\end{array}$} & \multicolumn{2}{|c|}{$\begin{array}{l}\text { Education } \\
\text { (years) }\end{array}$} & \multicolumn{2}{|c|}{$\begin{array}{c}\text { Exposure } \\
\text { (years) }\end{array}$} & \multirow{2}{*}{$\begin{array}{c}\text { Smoker } \\
\text { (\% of } \\
\text { subjects) }\end{array}$} & \multirow{2}{*}{$\begin{array}{c}\text { Drinkera } \\
\text { ( } \% \text { of } \\
\text { sutjects) }\end{array}$} \\
\hline & Mean & SD & Mean & SD & Mean & $S D$ & & \\
\hline $\begin{array}{l}\text { Exposed }(N=17) \\
\text { Reference }(N=17)\end{array}$ & $\begin{array}{l}36.6 \\
35.7\end{array}$ & $\begin{array}{l}12.2 \\
12.1\end{array}$ & $\begin{array}{l}6.3 \\
7.2\end{array}$ & $\begin{array}{l}1.4 \\
1.6\end{array}$ & $\begin{array}{r}7.4 \\
0\end{array}$ & 4.3 & $\begin{array}{l}76.5 \\
58.8\end{array}$ & $\begin{array}{l}50.0 \\
50.0\end{array}$ \\
\hline
\end{tabular}

a All of the subjects classified as "drinker" were occasional and social drinkers, ie, they drank less than once a month, each time no more than two large bottles of beer.

housekeeping department of a hospital. The referents were manual workers involved in the clearing of laundry and related items from the hospital wards. Their workplace was inspected to ensure that there was no exposure to any neurotoxic chemicals. None of the referents had any previous history of exposure to possible neurotoxic substances.

No marked differences were noted in the age, years of education, smoking, and drinking histories of the exposed and reference subjects (table 1). None of the exposed or reference subjects consumed more than $50 \mathrm{~g}$ of alcohol per day. Most of them were social drinkers, that is, drinking alcoholic drinks less than once per month. For the exposed group, the mean manganese exposure was 7.4 years with a range of $1-14$ years. Twelve $(71 \%)$ workers had more than five years of exposure.

\section{Exposure to manganese}

Plants A and B had been in the hygiene assessment program of the Department of Industrial Health since the early 1980s. Regular environmental monitoring of manganese air levels was conducted by hygienists of the Department, and the samples were analyzed by the toxicology laboratory of Singapore. Total airborne manganese concentrations were determined from personal samples taken from the breathing zone of workers randomly selected from the bagging sections only. A continuous sampling strategy was used. The average total sampling time per subject was about $6 \mathrm{~h}$. The details of the sampling and analysis methods have been discussed in an earlier paper (13). These data were compiled and showed the past exposure levels of manganese among the exposed workers. There had been no changes to the production processes or machinery in either of the factories throughout the period of monitoring.

Figure 1 shows the distribution of the mean and the $95 \%$ confidence intervals $(95 \% \mathrm{CI})$ of the manganese air levels in the packing areas by years for both factories. For some years (1982, 1983, 1987, and 1989) the environmental data were not available. The workers were generally exposed to higher levels of manganese in the early 1980s. Before 1985, the workers were exposed to manganese air levels exceeding the threshold limit value (TLV) of $5 \mu \mathrm{g} \cdot \mathrm{l}^{-1}$ (14). The mean manganese air level (from 1981 to
1991) for both the factories was 1.59 (95\% CI 1.19 1.99) $\mu \mathrm{g} \cdot \mathrm{l}^{-1}$.

In addition, both the exposed and reference subjects had venous blood and spot urine collected on the day of the neurobehavioral tests so that the manganese concentrations could be determined. The total manganese contents in blood and urine were determined by atomic absorption spectrophotometry (15). The exposed workers had markedly higher mean manganese levels in their blood, serum, and urine than the referents did (table 2).

\section{Study design}

None of the workers (exposed or referents) were taking any medication on the days they were tested for their neurobehavioral performance before starting work. Neither were they on any long-term medication. As a further precaution, the subjects were asked to abstain from alcoholic drinks $3 \mathrm{~d}$ prior to the test. Medical assessments were conducted to rule out conditions such as central or peripheral nervous system illness, musculoskeletal problems, or psychiatric disorders. The neurobehavioral tests were conducted on Monday mornings (between 0800 and

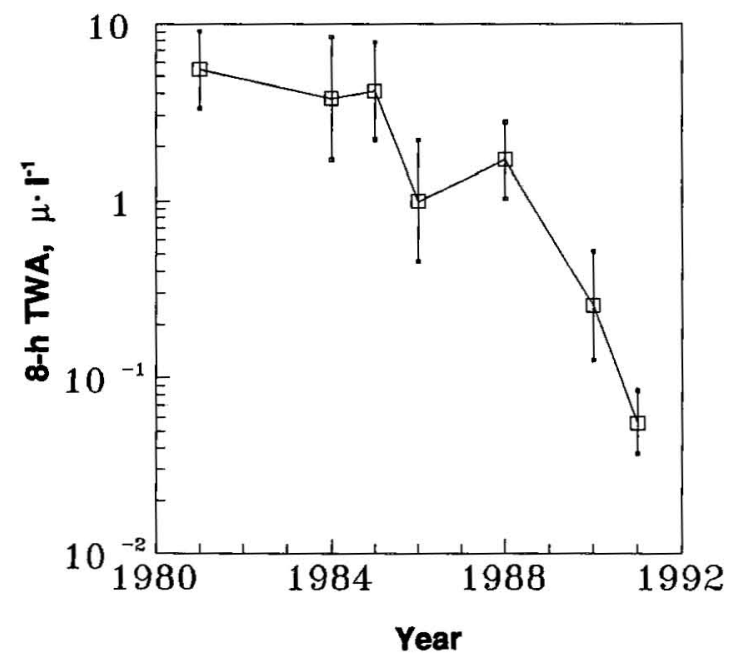

Figure 1. Mean levels of manganese in the air of the factories by calendar year. 
Table 2. Blood, serum, and urine manganese concentrations of the exposed workers and their referents.

\begin{tabular}{|c|c|c|c|c|c|c|}
\hline \multirow{2}{*}{ Group } & \multicolumn{2}{|c|}{$\begin{array}{c}\text { Blood manganese } \\
\left(\mu \mathrm{g} \cdot 1^{-1}\right)^{\mathrm{a}}\end{array}$} & \multicolumn{2}{|c|}{$\begin{array}{l}\text { Serum manganese } \\
\left(\mu \mathrm{g} \cdot 1^{-1}\right)^{\mathrm{a}}\end{array}$} & \multicolumn{2}{|c|}{$\begin{array}{c}\text { Urine manganese } \\
\qquad\left(\mu \mathrm{g} \cdot 1^{-1}\right)^{\mathrm{a}}\end{array}$} \\
\hline & Mean' & Range & Mean' & Range & Mean $^{b}$ & Range \\
\hline $\begin{array}{l}\text { Exposed } \\
\text { Reference }\end{array}$ & $\begin{array}{l}25.3 \\
23.3\end{array}$ & $\begin{array}{l}15.0-92.5 \\
17.3-30.1\end{array}$ & $\begin{array}{l}4.5 \\
3.9\end{array}$ & $\begin{array}{l}2.0-32.8 \\
1.5-6.4\end{array}$ & $\begin{array}{l}6.1 \\
3.9\end{array}$ & $\begin{array}{l}1.7-17.9 \\
0.7-9.6\end{array}$ \\
\hline
\end{tabular}

a $1 \mu \mathrm{g} \cdot \mathrm{I}^{-1}=0.018 \mu \mathrm{mol} \cdot \mathrm{I}^{-1}$.

b Geometric.

1000) after a weekend away from work exposure. The tests were carried out in the Department of Community, Occupational and Family Medicine in a room specially designed for neurobehavioral tests. Similarly, the referents were tested on Monday morning (between 0800 and 1100) so as to reduce the possible effects of circadian rhythm on test performance. The interview, questionnaire, and neurobehavioral tests were conducted blindly by the same trained field investigator throughout the study. The clinical examinations with special emphasis on the nervous system were conducted by one of the authors (SC). The clinical examination did not reveal any specific difference between the reference and exposed workers. None of the exposed workers or referents had any signs of cog-wheel phenomenon, rigidity of the neck and trunk, tremors of the fingers, or masklike faces.

Questionnaire. In the first part of the questionnaire, information was gathered on age, years of education, detailed occupational history, and actual and previous smoking habits. Alcohol intake was also documented carefully, as it could influence the findings. Actual amounts of alcohol consumption per day and number of years of drinking were noted.

In the second part of the questionnaire, a 37 subjective symptoms questionnaire taken from the Operational Guide for the WHO Neurobehavioral Core Test Battery (16) was used. The questions were mainly related to symptoms of the nervous system, such as decreased memory, fatigue, headache, giddiness, depressive feelings, sleep disturbances, weakness or numbness of the limbs, perspiration, tremor, irritability, anxiety, and autonomic system functions.

Neurobehavioral test battery. The WHO Neurobehavioral Core Test Battery (NCTB) (16) was used together with a few supplementary tests (17). The NCTB tests were as follows:

1. Digit span: In the digit span forward sequence tests the examiner reads aloud at regular intervals number sequences that increase from three to nine digits. The subject must repeat each sequence exactly as he or she hears it. The digit backward sequence runs from two to eight digits and must be repeated in the reverse order. The score is the total number of sequences correctly repeated in the two sections.

2. Santa Ana dexterity test: In the Santa Ana dexterity test a plastic base plate with pegs fitted in rows of 12 was used. Each peg was to be removed, turned 180 degrees and replaced in its slot. The objective is to turn as many pegs as possible in $30 \mathrm{~s}$. The test is repeated twice with the dominant hand and twice with the nondominant hand. The number of pegs successfully turned is recorded as the test score.

3. Digit symbol test: The digit symbol test worksheet contains a list of numbers that are associated with certain simple symbols and a list of random digits from one through nine with blank squares below each digit. The subject is required to fill the blank squares with the symbols paired to their corresponding digits and to do so as quickly as possible for $90 \mathrm{~s}$.

4. Benton visual retention test: The Benton visual retention test consists of 20 cards presented as 10 pairs of two. The first of each pair contains the pattern to be memorized, and the second contains four patterns, one of which is identical to the pattern presented previously. After looking at each card presented for $10 \mathrm{~s}$, the subject must recognize the right patterns among the confounders in the next card presented immediately thereafter.

5. Pursuit aiming test: The pursuit aiming test requires the subject use a pencil to place one dot inside each circle following the pattern given on the printed pursuit aiming test sheet. This task is to be performed as quickly as possible for $60 \mathrm{~s}$.

The additional supplementary tests were as follows:

Finger tapping: In the finger-tapping test (18), an instrument supplied by Lafayette Instrument was used. The subject has to tap as quickly as possible with his or her index finger for $10 \mathrm{~s}$. The performance is represented by the average number of five trials.

Trail making test: In the trail making test (19), the subject has to join 25 circles containing the numbers 
from 1 to 25 in the correct numerical sequence. The time taken to complete each series is recorded.

Nerve conduction. Nerve conduction studies were performed by a trained technician from a neurology laboratory for each subject after he had completed the neurobehavioral tests. Measurements were made with a Medelec electrophysiological system (model MS6, Skovlunde, Denmark) with two-channel averaging facilities. Tracings were recorded on light sensitive paper. The room temperature was maintained constantly at $30-31^{\circ} \mathrm{C}$, and skin impedance was kept below $10 \mathrm{~K} \Omega$ for all of the recordings.

The maximum motor conduction velocity and the distal motor latency of the median and ulnar nerves were determined in the dominant forearm. The median nerve was stimulated at the wrist $(13 \mathrm{~cm}$ from the base of the forefinger) and at the elbow. The maximum motor conduction velocity and distal latency of the ulnar nerve were obtained by stimulation at the lateral aspect of the wrist $(10 \mathrm{~cm}$ from the base of the little finger) and just below the medial epicondyle. The muscle action potential of the thenar (for the median nerve) and hypothenar (for the ulnar nerve) muscles were recorded with surface disc electrodes.

The maximum sensory nerve conduction velocity of the median nerve was measured by stimulating the forefinger with ring electrodes and recording orthodromically at the wrist $(13 \mathrm{~cm}$ from the base of the forefinger). The conduction velocity of the ulnar nerve was recorded by stimulating the little finger with ring electrodes and recording orthodromically at the lateral aspect of the wrist $(10 \mathrm{~cm}$ from the base of the little finger).

\section{Statistical analysis}

Statistical analysis was performed with the Statistical Analysis System package on an IBM 3081 mainframe computer. Logarithmic transformation of the biological data was used to obtain a more normal distribution. The Wilcoxon rank-sums test was used to test for any significant differences between the exposed and referents' neurophysiological parameters and neurobehavioral test scores because of the small sample size. Fisher's exact test was used when the symptom prevalence was compared between the two groups.

\section{Results}

\section{Subjective symptoms}

Figure 2 shows the prevalence of symptoms related to the nervous system in the exposed and reference groups. Among the 37 symptoms sought, 20 were more frequently reported in the exposed group. However, a significantly higher prevalence was noted only in relation to insomnia and profuse sweating.

\section{Neurophysiological and neurobehavioral functions}

The mean values of the neurophysiological parameters are shown for the exposed workers and the ref-

\section{Symptoms}

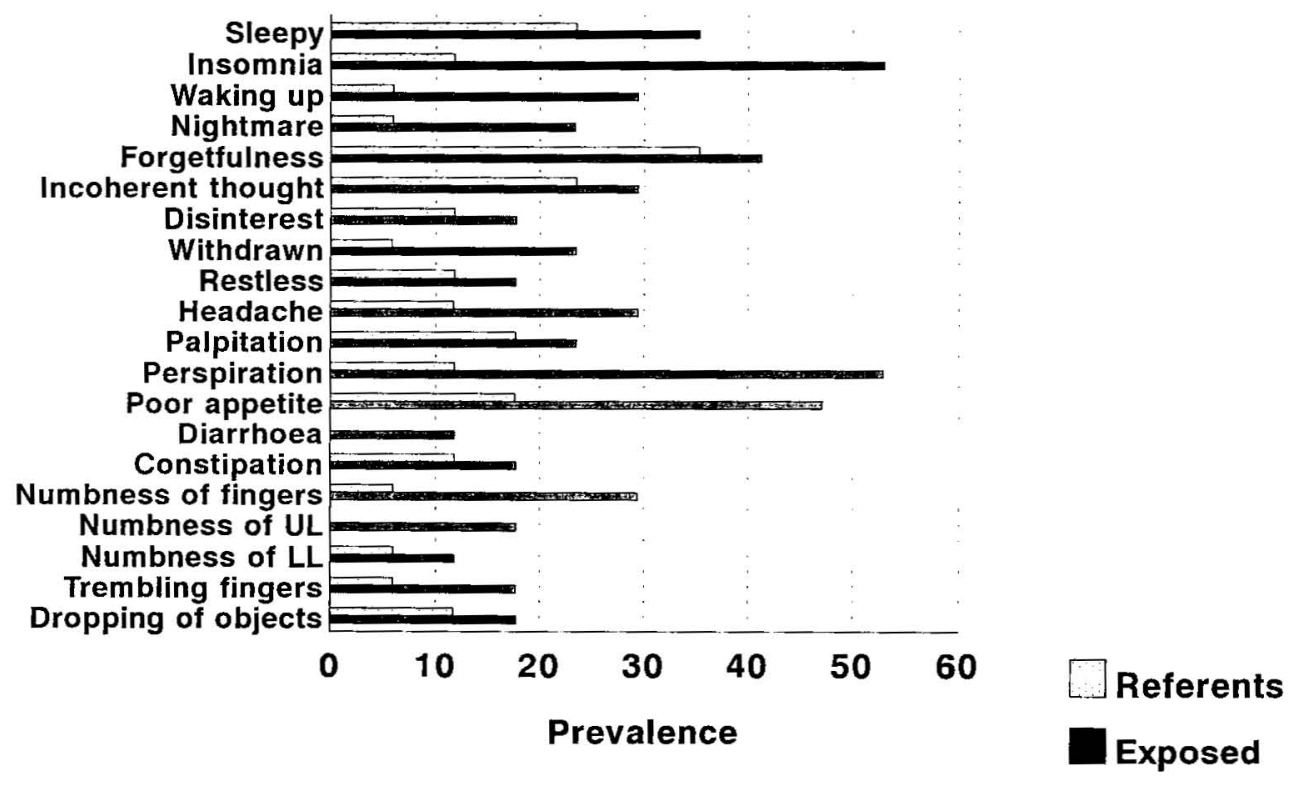

Figure 2. Prevalence (\%) of symptoms in the reference and exposed groups. (UL = upper limbs, $L L=$ lower limbs) 
Table 3. Neurophysiological data from the exposed workers and their referents. ${ }^{a}$

\begin{tabular}{|c|c|c|c|c|c|c|c|c|c|c|c|c|}
\hline \multirow{3}{*}{ Group } & \multicolumn{6}{|c|}{ Median nerve } & \multicolumn{6}{|c|}{ Ulnar nerve } \\
\hline & \multicolumn{2}{|c|}{$\begin{array}{l}\text { Sensory } \\
\text { conduction } \\
\text { velocity } \\
\left(\mathrm{m} \cdot \mathrm{s}^{-1}\right)\end{array}$} & \multicolumn{2}{|c|}{$\begin{array}{l}\text { Motor } \\
\text { conduction } \\
\text { velocity } \\
\left(\mathrm{m} \cdot \mathrm{s}^{-1}\right)\end{array}$} & \multicolumn{2}{|c|}{$\begin{array}{c}\text { Distal } \\
\text { latency } \\
(\mu \mathrm{V})\end{array}$} & \multicolumn{2}{|c|}{$\begin{array}{l}\text { Sensory } \\
\text { conduction } \\
\text { velocity } \\
\left(\mathrm{m} \cdot \mathrm{s}^{-1}\right)\end{array}$} & \multicolumn{2}{|c|}{$\begin{array}{c}\text { Motor } \\
\text { conduction } \\
\text { velocity } \\
\left(\mathrm{m} \cdot \mathrm{s}^{-1}\right)\end{array}$} & \multicolumn{2}{|c|}{$\begin{array}{c}\text { Distal } \\
\text { latency } \\
(\mu \mathrm{V})\end{array}$} \\
\hline & Mean & SD & Mean & SD & Mean & SD & Mean & SD & Mean & SD & Mean & SD \\
\hline $\begin{array}{l}\text { Exposed } \\
\text { Reference }\end{array}$ & $\begin{array}{l}45.9 \\
49.7\end{array}$ & $\begin{array}{l}5.1 \\
8.1\end{array}$ & $\begin{array}{l}54.0 \\
58.4\end{array}$ & $\begin{array}{l}5.6 \\
6.7\end{array}$ & $\begin{array}{l}4.1 \\
4.0\end{array}$ & $\begin{array}{l}0.5 \\
0.9\end{array}$ & $\begin{array}{l}44.3 \\
48.3\end{array}$ & $\begin{array}{l}5.4 \\
5.9\end{array}$ & $\begin{array}{l}56.6 \\
57.2\end{array}$ & $\begin{array}{l}3.9 \\
4.9\end{array}$ & $\begin{array}{l}3.4 \\
3.1\end{array}$ & $\begin{array}{l}0.5 \\
0.5\end{array}$ \\
\hline
\end{tabular}

a The Wilcoxon Rank-sums test showed no significant differences between the neurophysiological data of the two groups.

Table 4. Effects of manganese on neurobehavioral function.

\begin{tabular}{|c|c|c|c|c|c|c|c|c|c|c|c|c|c|c|c|c|c|c|c|c|c|c|}
\hline \multirow{3}{*}{ Group } & \multicolumn{4}{|c|}{ Santa Ana } & \multicolumn{4}{|c|}{ Finger tapping } & \multirow{2}{*}{\multicolumn{2}{|c|}{$\begin{array}{l}\text { Benton } \\
\text { visual } \\
\text { retention }\end{array}$}} & \multirow{2}{*}{\multicolumn{2}{|c|}{ Digit span }} & \multirow{2}{*}{\multicolumn{2}{|c|}{$\begin{array}{l}\text { Digit } \\
\text { symbol }\end{array}$}} & \multicolumn{6}{|c|}{ Pursuit aiming } & \multirow{2}{*}{\multicolumn{2}{|c|}{ Trail making }} \\
\hline & \multicolumn{2}{|c|}{$\begin{array}{c}\text { Dominant } \\
\text { hand }\end{array}$} & \multicolumn{2}{|c|}{$\begin{array}{l}\text { Non- } \\
\text { dominant } \\
\text { hand }\end{array}$} & \multicolumn{2}{|c|}{$\begin{array}{l}\text { Dominant } \\
\text { hand }\end{array}$} & \multicolumn{2}{|c|}{$\begin{array}{l}\text { Non- } \\
\text { dominant } \\
\text { hand }\end{array}$} & & & & & & & \multicolumn{2}{|c|}{ Correct } & \multicolumn{2}{|c|}{ Incorrect } & \multicolumn{2}{|c|}{$\begin{array}{c}\text { Sum of } \\
\text { correct and } \\
\text { incorrect }\end{array}$} & & \\
\hline & Mean & SD & Mean & SD & Mean & $\mathrm{Sd}$ & Mean & SD & Mean & SD & Mean & SD & Mean & SD & Mean & SD & Mean & SD & Mean & SD & Mean & $S D$ \\
\hline $\begin{array}{l}\text { Ex: } \\
\text { posed }\end{array}$ & 17.4 & 2.5 & 16.0 & 2.4 & 41.2 & 7.7 & 41.6 & 11.9 & 6.8 & 1.9 & 11.6 & 4.0 & 34.0 & 12.1 & 146.5 & 40.5 & 3.4 & 6.9 & 149.9 & 43.2 & 49.1 & 24.9 \\
\hline $\begin{array}{l}\text { Refer- } \\
\text { ence }\end{array}$ & 18.1 & 2.3 & 17.9 & 2.4 & 48.7 & 6.6 & 43.9 & 6.1 & 7.9 & 1.4 & 13.4 & 2.6 & 46.5 & 11.8 & 188.8 & 28.8 & 5.8 & 11.1 & 194.6 & 31.7 & 33.4 & 6.8 \\
\hline $\begin{array}{l}\text { P. } \\
\text { values }\end{array}$ & \multicolumn{2}{|c|}{0.36} & \multicolumn{2}{|c|}{0.03} & \multicolumn{2}{|c|}{0.01} & \multicolumn{2}{|c|}{0.16} & \multicolumn{2}{|c|}{0.03} & \multicolumn{2}{|c|}{0.08} & \multicolumn{2}{|c|}{0.01} & \multicolumn{2}{|c|}{0.00} & \multicolumn{2}{|c|}{0.80} & \multicolumn{2}{|c|}{0.00} & \multicolumn{2}{|c|}{0.03 . } \\
\hline
\end{tabular}

erents in table 3 . There was no significant difference for any of the parameters tested.

Table 4 shows the results of the neurobehavioral tests. The exposed group had poorer scores on all of the tests. Significant differences were observed for The Santa Ana dexterity test for the nondominant hand, finger tapping for the dominant hand, the Benton visual retention test, the digit symbol test, the pursuit aiming test (correct and sum), and the trail making test. No significant correlation was observed between the test scores and the blood, serum, and urine manganese concentrations of each worker. The best correlation coefficient $(\mathrm{r}=-0.47)$ was for blood manganese and the digit symbol test.

\section{Discussion}

One of the limitations of this study was the small sample size, which was unavoidable because there are only two manganese ore milling plants in Singapore. The study included all workers who had more than one year's exposure and currently worked in the manganese ore mills in Singapore. An attempt was made to obtain a list of workers who had worked but subsequently left the two factories, but this was not possible as most were foreigners who had returned to their native countries. Thus this study was limited to the current work force.

It would have been possible to study other groups of workers with exposure to manganese, for example, welders, smelters, or dry-cell battery workers, but invariably they would also have been exposed to other possible neurotoxic metals such as lead or mer- cury. These exposures would have confounded the results of the study.

The small sample size could have reduced the possibilities to observe a statistically significant correlation between the neurobehavioral test scores and the biological parameters. However, it is also true that the exposure indices used were not reflective of past exposure, which could have been much higher.

The other possible limitation of this study was the selection of the reference group. It can be argued that the reference workers, being hospital staff, may not have been comparable with factory workers. It may be true that the two groups differed as to their types of work, but they were comparable as to age and years of education and had similar manual activities (carrying bags of manganese ore versus carrying bags of laundry). Therefore, the selection of this reference group of hospital staff was unlikely to affect the results.

The manganese air levels were low in both factories. But this was not so in the early 1980s (figure 1). In an earlier cross-sectional study (conducted in 1983), also involving these two mills, Gan et al (13) reported a mean manganese air level of $4.16 \mu \mathrm{g} \cdot \mathrm{l}^{-1}$ $\left(0.076 \mu \mathrm{mol} \cdot \mathrm{I}^{-1}\right)$ in the 28 personal environmental $(8 \mathrm{~h})$ samples obtained. Fifteen of these samples exceeded the exposure limit of $5 \mu \mathrm{g} \cdot \mathrm{l}^{-1}(0.09 \mu \mathrm{mol}$. $\left.1^{-1}\right)$. Our subjects, therefore, were likely to have been exposed to higher levels of manganese dust in the past. Seventy-one percent $(N=12)$ of the exposed workers had at least five years of exposure. On the average, the exposure period probably began before or in 1986. The mean concentration of manganese 
in the ambient air in 1986 was $0.99 \mu \mathrm{g} \cdot \mathrm{1}^{-1}$ $\left(0.018 \mu \mathrm{mol} \cdot 1^{-1}\right)$ with a range of 0.20 to $7.80 \mu \mathrm{g} \cdot 1^{-1}$ $\left(0.004\right.$ to $\left.0.142 \mu \mathrm{mol} \cdot 1^{-1}\right)$.

The most characteristic signs of chronic manganese intoxication are related to the central nervous system. Our investigation was designed to detect possible early neurological effects of manganese. A standardized neurological examination was not very useful in detecting any early neurological effects in our study. None of the exposed subjects examined had any signs of chronic manganese poisoning. These observations are in agreement with those of other reports $(20,21)$.

The prevalence of the symptoms insomnia and perspiration were significantly higher among the exposed subjects. These symptoms have been reported earlier. The investigation by Suziki et al (see the original article in reference 22 ) in two ferromanganese factories showed that, in one factory in which the manganese air concentration ranged from 1.9 to $4.9 \mathrm{mg} \cdot \mathrm{m}^{-3}, 30 \%$ of the workers complained of failing memory, fatigue, and increased perspiration. Hunter (23) reported sleep disturbances among manganese miners with chronic poisoning caused by the inhalation of manganese dust.

There were no significant differences in the basic nerve conduction tests involving the sensory and motor components of the median and ulnar nerves of the dominant forearm between the exposed workers and the referents. This finding confirms the results of other studies, which showed that manganese is not likely to affect the peripheral nervous system. The nerve conduction tests were also done to ensure that we did not include any individual with peripheral neuropathy.

Parkinson's disease is a disturbance of motor function characterized chiefly by a slowing of voluntary movement, akinesia, muscular rigidity, and tremor. Workers with manganese poisoning develop a syndrome that closely resembles Parkinson's disease. Tremor, bradykinesia, gait disturbance, and micrographia may be present, followed by slow and montonous speech, and a masked face (23). Although the exposed workers did not have clinical signs of Parkinson's disease, the results of the neurobehavioral tests are suggestive of some degree of motor dysfunction. In the Santa Ana test involving the nondominant hand, the exposed group did significantly worse than the referents. Similarly, motor speed (finger-tapping test) involving the dominant hand was slower than among the referents. Our findings agree with those of Wennberg and his co-workers' studies of manganese-exposed workers (10).

Matthews et al (24) reported evidence of delayed initiation in motor performance among individuals with early parkinsonism. The delayed initiation of motor performance could affect the performance of finger tapping and the Santa Ana test. That the exposed subjects fared significantly poorer than the referents in the finger tapping and Santa Ana tests may be suggestive of a disturbance of motor function similar to Parkinson's disease.

Motor dysfunction was further substantiated by the significantly poorer aiming pursuit scores among the exposed subjects (table 4). The aiming pursuit test, which basically assesses motor steadiness, measures the ability to make quick and accurate movements with the hand (25). Roel et al (21) reported that the prevalence of abnormally elevated scores on the hand steadiness test (using the hole tremormeter) was significantly higher for their manganese workers than for their referents. Similarly their overall evaluation of the orthokinesimeter parameters (mean values and cumulative frequency distributions) indicated that the eye-hand coordination of their exposed group was significantly less precise and more uncertain than that of the reference group. All of their subjects had a standardized neurological examination that was essentially normal.

Parkinsonism patients are also known to have specific impairments of cognitive functioning. These impairments include slowed scanning on a visual recognition task (26) and slowing on motor response tasks that can reflect both bradykinesia and a central defect of motor programming (24). Mortimer et al (27) and Pirozzolo et al (28) observed that, among parkinsonism patients, bradykinesia correlated significantly with poorer performances on tests involving psychomotor speed, visual-spatial performances, and memory for spatial orientation. Our exposed group also performed significantly worse on tests involving visual motor and attention response speed (digit symbol and trail making). The poorer test scores may be reflective of subclinical bradykinesia among the exposed subjects.

There was no clinical evidence of any motor dysfunction among the exposed subjects. This result was supported by the normal clinical examination and nerve conduction findings (table 3 ). However, significant deficiencies were elicited in the neurobehavioral tests involving motor function; this result may be suggestive of an early Parkinson-like disorder. It would therefore suggest that the method currently used to examine manganese-exposed workers clinically would not serve much purpose in the early detection of health effects of manganese.

Considering the findings of this study, it may be more appropriate for exposed subjects to undergo a test battery for neurobehavioral functions, for example, WHO's NCTB. The test battery could be done on a regular basis. In indicating early changes in the health of manganese workers, changes in the serial results of exposed workers would be better than a clinical examination.

\section{Acknowledgments}

This study was carried out with research grant RP3920390 from the National University of Singapore. 


\section{References}

1. Couper J. On the effect of black oxide of manganese when inhaled into the lungs. Br Ann Med Pharmacol $1837 ; 1: 41-2$.

2. Casamajor L. An unusual form of mineral poisoning affecting the nervous system: manganese. JAMA $1913 ; 60: 646-9$.

3. Nazif M. Manganese as an industrial poisoning. J Egypt Public Health Assoc 1936; 10:1-20.

4. Celesia GC, Marsden CD. Psychiatric disturbances in Parkinson's disease. Dis Nerv Syst 1972;33:577-83.

5. Cook DG, Fahn S, Brait KA. Chronic manganese intoxication. Arch Neurol 1974;30:59-64.

6. Politis MJ, Schaumburg HH, Spencer PS. Neurotoxicity of selected chemicals. In: Spencer PS, Schaumburg $\mathrm{HH}$, ed. Experimental and clinical neurotoxicology. Baltimore, MD: Williams \& Wilkins, 1980 $618-9$.

7. Adams RD, Victor M. Principles of neurology. 3rd ed. New York, NY: McGraw Hill, 1985.

8. Mana I. Manganese poisoning. In: Vinken PJ, Bruyn GW, ed. Handbook of clinical neurology; vol 36. Amsterdam: Elsevier North-Holland 1979:217-38.

9. Dreibach RH, Robertson WO. Handbook of poisoning. 12th ed. East Norwalk, CT: Prentice-Hall International, 1990:236-7.

10. Wennberg A, Iregren A, Struwe G, Cizinsky G, Hagman M, Johansson L. Manganese exposure in steel smelters a health hazard to the nervous system. Scand J Work Environ Health 1991; 17:255-62.

11. International Labour Organisation (ILO). Encyclopaedia on occupational health \& safety. 3rd ed. Geneva: ILO, 1983:1200-4\&1332-5.

12. Hua MS, Huang CC. Chronic occupational exposure to manganese and neurobehavioral function. J Clin Exp Neuropsychol 1991;13(4):495-507.

13. Gan SL, Tan KT, Kwok SF. Biological threshold limit values for manganese dust exposure. Singapore Med J 1988;29:105-9.

14. American Conference of Governmental Industrial Hygienists (ACGIH). Threshold limit values for chemical substances and physical agents and biological exposure indices for 1991-1992. Cincinnati, OH: ACGIH, 1991.

15. Brodie KG, Routh MW. Trace analysis of lead in blood, aluminium and manganese in serum and chronium in urine by graphite furnace atomic absorption spectrometry. Clin Biochem 1984;17:19-26.

16. Johnson BL. Operational guide for the WHO neurobehavioral core test battery. Geneva: World Health Organization, Office of Occupational Health, 1990.

17. Ngim CH, Foo SC, Boey KW, Jeyaratnam J. Chronic neurobehavioral effects of elemental mercury in dentists. Br J Ind Med 1992;49:782--90.

18. Matthews $\mathrm{CG}$, Klove $\mathrm{H}$. Instruction manual for the adult neuropsychology test battery. Madison, WI: Madison University of Wisconsin Medical School, 1979.

19. Reitan RM. Validity of the Trail Making Test as an indication of organic brain damage. Percept Mot Skills 1958;8:271-6.

20. Saric M, Markieevie A, Hrustic O. Occupational exposure to manganese. Br J Ind Med 1977;34:114-8.

21. Roels H, Lauwerys SR, Buchet JP, Genet P, Sarhan MJ, Hanotiau I, et al. Epidemiological survey among workers exposed to manganese: effects on lung, central nervous system, and some biological indices. Am J Ind Med 1987;11:307-27.

22. Johnson BL. Prevention of neurotoxic illness in working populations. New York, NY: John Wiley \& Sons, 1987:40-1.

23. Donald H. The diseases of occupations. 4th ed. Boston, MA: Little, Brown and Company, 1969:460-5.

24. Matthews CG, Haaland KY. The effect of symptoms during congnitive and motor performance in parkinsonism. Neurology 1979;29:951-6.

25. Fleischman EA. Dimensional analysis of psychomotor abilities. J Exp Psychol 1954;48:437-54.

26. Wilson RS, Kasznaik AW, Klawans HL, Garron DC. High speed memory scanning in parkinsonism. Cortex 1980;16:67-72.

27. Mortimer JA, Pirozzolo FJ, Hansch EC, Webster DD. Relationship of motor symptoms to intellectual deficits in Parkinson disease. Neurology 1982;32:1337.

28. Pirozzolo FJ, Hansch EC, Mortimer JA. Dementia in Parkinson disease: a neuropsychologial analysis. Brain Cogn 1982;1:71-83.

Received for publication: 23 November 1992 